\title{
Torture Approval in Comparative Perspective
}

\section{Peter Miller}

Published online: 17 February 2011

(C) The Author(s) 2011. This article is published with open access at Springerlink.com

\begin{abstract}
Torture is (almost) universally condemned as barbaric and ineffective, yet it persists in the modern world. What factors influence levels of support for torture? Public opinion data from 31 countries in 2006 and 2008 (a total of 44 country-years) are used to test three hypotheses related to the acceptability of torture. The findings, first, show that outright majorities in 31 country-years reject the use of torture. Multiple regression results show that countries with high per capita income and low domestic repression are less likely to support torture. Constraints on the executive have no significant effect on public opinion on torture.
\end{abstract}

Keywords Torture $\cdot$ Personal integrity $\cdot$ Public opinion $\cdot$ Comparative politics

In a statement released by the White House on June 26, 2003-the International Day in Support of Victims of Torture-President George W. Bush declared

The United States is committed to the world-wide elimination of torture and we are leading this fight by example. I call on all governments to join with the United States and the community of law-abiding nations

The author thanks Neil Chaturvedi, Russell Dalton, Darius Rejali, Wayne Sandholtz, Kendall Taggart, Albert Wolf, and three anonymous reviewers for comments on previous drafts of this paper. A previous version of this paper was presented to the 2010 meeting of the Western Political Science Association in San Francisco, CA and to the 9th Center for the Study of Democracy conference.

P. Miller $(\bowtie)$

Department of Political Science and Center for the Study of Democracy,

University of California, Irvine, CA 92697, USA

e-mail: peterm@uci.edu 
in prohibiting, investigating, and prosecuting all acts of torture and in undertaking to prevent other cruel and unusual punishment. I call on all nations to speak out against torture in all its forms and to make ending torture an essential part of their diplomacy.

At about the same time of this statement, American soldiers were perpetrating acts of torture, most notably at the Abu Ghraib prison complex in Iraq, but also at other locations, including the detention facility at Guantánamo Bay, Cuba and Bagram Airfield in Afghanistan. Subsequently, the Bush administration disclosed that interrogators used a water torture technique on three detainees; one of the three, Khalid Sheikh Mohammad, was subjected to this technique 183 times. Twenty-eight other detainees were subjected to other, "enhanced" techniques. Something is amiss when the USA is both a perpetrator of and advocate for the elimination of torture.

This episode is another example of the dictum: "in the study of torture, hell is in the details" (Rejali 2007, 63). American policymakers, faced with a high demand for intelligence to use in a military conflict, resorted to torture to acquire information. The use of torture in these circumstances, in itself, is historically unremarkable; throughout history many governments have resorted to torture in a wartime context. The recent American use of torture, however, is historically distinct because it occurred against the backdrop of a series of cross-national surveys that allow government policy to be analyzed in the context of public opinion. This paper compares national rates of torture approval with data on per capita income, constraints on executive power, and domestic repression.

Torture is defined and expressly forbidden by the international Convention Against Torture (CAT). Article I of the CAT defines torture as

any act by which severe pain or suffering, whether physical or mental, is intentionally inflicted on a person for such purposes as obtaining from him or a third person information or a confession, punishing him for an act he or a third person has committed or is suspected of having committed, or intimidating or coercing him or a third person, or for any reason based on discrimination of any kind, when such pain or suffering is inflicted by or at the instigation of or with the consent or acquiescence of a public official or other person acting in an official capacity. It does not include pain or suffering arising only from, inherent in or incidental to lawful sanctions.

This convention was adopted by the United Nations General Assembly in December 1984 and entered into force in June 1987. One hundred forty-six countries have ratified this treaty. Of the 31 countries in this study, only India (which has signed, but not ratified the treaty), Iran, and Iraq are not members of the CAT; the Palestinian Territories are not full members of the United Nations. Further, more than half of the surveyed countries (17 of 31) explicitly 
ban the use of torture in their constitution. ${ }^{1}$ This evidence suggests that a right to be secure from torture is nearly universal, but torture clearly persists in the modern world, perhaps in accordance with public opinion. ${ }^{2}$

This study expands the literature on torture in several ways. First, it complements and extends studies of public opinion on the acceptability of torture based in the USA (Gronke et al. 2010; Richards and Anderson 2007) to 30 other countries in the world. Torture is not solely an American phenomenon and thus should be examined in a comparative context. Second, it focuses on a particular form of state violence, previously addressed in the general terms of human rights or personal integrity (Carlson and Listhaug 2007; Anderson et al. 2002 , 2005). These studies have generally found mass perceptions of human rights practices follow expert evaluations of the same. This study focuses in on one type of domestic repression to see if the general explanations fit the specific case of torture. Lastly, this study broadens research on dynamic representation, with specific attention to torture, to include cross-national survey data (Richards and Anderson 2007; Heath et al. 2005; Stimson et al. 1995). With these data, we can examine the link between government policy positions designed to reflect popular opinion (e.g., ratifying the CAT) and actual practices (e.g., resorting to clean torture techniques).

Two surveys from 2006 and 2008 conducted in part by the Program on International Policy Attitudes (PIPA) at the University of Maryland ask the public in 31 countries about their support for torture. Three hypotheses related to public approval of torture are generated from the literature on personal integrity rights. The general argument of this paper is that, while approval of torture anywhere is rare, countries with high levels of per capita income and low levels of domestic repression exhibit higher levels of opposition to torture than other countries, ceteris paribus. Democratic consolidation—operationalized as

\footnotetext{
${ }^{1}$ This calculation does not include countries, like the USA and Canada, where the constitution only mentions a less specific ban on cruel treatment and the like or cases, such as the UK and Israel, that have no formal, written constitution as states that have included a ban on torture in their constitution.

${ }^{2}$ Definitions of torture abound, but it is beyond the scope of this paper to attempt to reconcile the various ways torture is conceptualized. On a practical level, we are unaware of any surveys outside the USA that ask respondents to categorize a set of techniques as torture or as cruel, inhumane, and degrading treatment-Parry (2010) observes that while the former category is well-defined in international law, the latter is quite vague. The definition of torture as elaborated in the CAT is a useful point for departure because it specifies a set of techniques countries cannot use for the purposes of information, confession, intimidation, or coercion. Other definitions of torture exist in the literature-for example, Rejali (2007) only considers the physical infliction of pain to rise to the level of torture-but do not carry with them either the weight of cross-national concurrence of meaning or an agreement to eliminate the practices that are identified in the CAT. While the American population may disagree at times on which specific interrogation techniques are torture (Gronke et al. 2010; Richards and Anderson 2007), survey data from 55 countries suggest that the general public's evaluations of the concepts of human rights and torture match those of experts (Carlson and Listhaug 2007). Individuals may diverge on which specific techniques are classified as torture, but the core character of torture is most likely similar across different national contexts.
} 
limitations on the power of the executive-has no significant effect on public approval of torture.

\section{Predicting Public Support for Torture}

One might expect that political scientists, given their proclivity to see the state as the central unit of analysis, would have many insights about the persistence and diffusion of torture. However, this is not the case. "To date, researchers have paid far more attention to the evils done against governments (and citizens) by dissidents, rebels, and terrorists than to the evils done by presidents, the police, military, secret service, national guard, and death squads against those within their territorial jurisdiction" (Davenport 2007a, 1). This literature on repressive state actions largely considers torture as part of a general class of personal integrity violations, including harassment, surveillance, arrests, and mass killing.

Other scholars have considered the causes and consequences of torture in its own right. Torture is commonly used as a tool of civic discipline, dividing society between citizens-who cannot be tortured-and liminal members of society - who may be tortured when deemed necessary (Parry 2010; Einolf 2007). As an example of torture as a tool of civic discipline, Rejali mentions the case of a security guard in San Diego who "patrolled the Gaslamp Quarter as 'Clancy the Cop' [and] used his new stun gun on transients" $(2007,59)$. Violence Workers explores motivations of torturers active during the military regime in Brazil (Huggins et al. 2002). Conroy (2000) examines the persistence of torture in Northern Ireland, Israel, and Chicago.

The techniques states use to torture have changed over time. The rise of non-scarring torture techniques is one result of the emergence and growth of a global human rights monitoring regime following from the founding of Amnesty International and other organizations in the 1960s (Rejali 2007). Simply put, when the world is watching, torturers conceal their activities through techniques that are not as easily detected. Democratic states, being open to scrutiny from the monitoring regime and a free press, tend to innovate non-scarring torture techniques. For example, Israeli interrogators changed how they treated Palestinian prisoners sometime between 1991 and 1992, but the standard, scarring treatment remained in use during the Israeli occupation of southern Lebanon (Ron 1997).

Comparative studies tend to emphasize two factors that are often associated with violations of personal integrity: economic development and democratic consolidation (Milner et al. 1999; Mitchell and McCormick 1988). Quantitative studies of personal integrity violations provide a third relevant explanatory variable in the form of a measure for the frequency of these violations. The presence (or absence) of domestic repression may color if people approve of torture. Further, economic development and democratic consolidation imply a rejection of torture and other violations of personal integrity. Before addressing the data used in this study, the linkages between economic development, 
democratic consolidation, and domestic repression and public approval of torture are addressed in turn.

\section{Economic Development}

Economic development is linked to greater support for protection of human rights. Increasing income levels have been shown to reduce violations of personal integrity rights (Poe et al. 1999; Henderson 1991). Economic development also leads to integration with the global economic system, further enshrining protection of rights to personal integrity (Richards et al. 2001; Cingranelli and Richards 1999a). ${ }^{3}$ Lastly, survey data suggest that per capita GDP is positively associated with more accurate perceptions of human rights in general and torture in particular (Carlson and Listhaug 2007).

A more informed and educated public is a product of economic growth. Further, sustained economic growth-and the accompanying decrease in risk of starvation-is associated with a set of changes in value orientations, away from "materialist" survival-based needs and toward "postmaterialist" values of self-expression and liberty (Inglehart 1990, 1997). Over time, self-expression values give rise to a new type of humanist society that promotes emancipation on many fronts, what Inglehart and Welzel term the "humanistic transformation of modernization" (2005, 47). Similarly, Inkeles and Smith find that modernization leads individuals to feel less alienated, anomic, and hostile to other groups in society $(1974,296)$. These processes of value change lead to a public that is "relatively intolerant of measures that violate civil rights, personal integrity and human dignity" (Inglehart and Welzel, 126 fn. 9, emphasis in original). Inglehart and Welzel even relate their work on value change to torture. "Genital mutilation of women is still practiced in a number of societies, but it is becoming viewed as unacceptable in most societies, including a majority of Islamic societies. The use of torture is on a similar trajectory" (293). This assertion is not addressed elsewhere in the text; the present study can provide a link between postmaterialist value change and torture.

\section{Democracy and Constrained Executives}

A second stream of the literature links support for human rights-and opposition to torture - to the consolidation of democratic institutions and norms. Democracy is rooted in two values: equality and participation (Dahl 1971; Verba et al. 1978). Ancient democrats in Greece and Rome had no objection to using torture as a matter of course in legal trials. However, modern

\footnotetext{
${ }^{3}$ The piece by Richards et al. $(2001,231)$ also finds that economic development generally is associated with less respect for human rights. This finding is in contrast with most other research on the subject. The authors speculate that this finding may be due to restricting their sample to developing countries (and not the standard global sample) or that it is suggestive of burgeoning unrest following from increased economic inequality.
} 
conceptions of democracy have long since rejected torture in court proceedings and elsewhere in society. Therefore, we should expect citizens in a democratic state, acculturated to norms of equality, to disapprove of torture.

While cognizant that democracy refers to a multidimensional set of related concepts, social science research has identified a series of specific institutions that are associated with greater respect for human rights. Abuse of human rights is reduced in a multi-party environment (Bueno de Mesquita et al. 2005). The use of low magnitude proportional representation districts and an open list electoral system is further associated with fewer abuses (Cingranelli and Filippov 2010). A free press and popular suffrage (Conrad and Moore 2010) and an independent judiciary (Powell and Staton 2009) contribute to greater respect for human rights. The regular timing of free and fair elections and limits on executive power-necessary conditions for democratic consolidationsuggest fewer abuses of human rights by government agents. ${ }^{4}$ In sum, constraining the power of the executive within the government is one way to reduce violations of personal integrity.

Davenport $(1999,2004)$ claims that democracy pacifies internal repression. Henderson (1991) finds that democratic consolidation is related to less frequent violations of personal integrity rights. Conversely, Poe et al. (1999) conclude that military regimes are associated with higher rates of violations of personal dignity. Zanger (2000) not only critiques the explanatory power of regime type but also finds that democracy is associated with lower rates of repression.

However, the consolidation of democracy is not a deterministic factor limiting domestic repression (Davenport 2007b). Hathaway (2002) finds that democracies that ratify the CAT have a worse record on torture than democracies that do not ratify the Convention. Rejali (2007) also deemphasizes the importance of regime type; the critical intervening variable is a human rights monitoring regime.

A more nuanced claim argues that any democratic peace dividend is realized only when the transition process passes a certain threshold of democratization (Bueno de Mesquita et al. 2005; Davenport and Armstrong 2004). Fein (1995) argues that personal integrity violations are more likely among countries that have extended but not institutionalized democracy, what is termed the "more murder in the middle hypothesis." Regan and Henderson (2002) find a curvilinear relationship between regime type and political repression;

\footnotetext{
${ }^{4}$ It is important to note that any government is comprised of coalitions, which are rarely monolithic. Unelected elements of the ruling coalition may have different incentives for following public opinion. The security services, as one example of a state institution that may be less responsive to public opinion, may be driven by security rationalities that are ambivalent—or even, at times, contrary-to established democratic norms. However, the tradition in established democracies of supreme civilian rule would suggest that even military and intelligence agencies are accountable to elected civilian leaders.
} 
semi-democratic states have the highest rates of repression. This literature concludes that transitional states are the most vulnerable to torture and other repressive governmental actions.

\section{Domestic Repression}

A third stream in the literature focuses on the actual treatment of a population by the state, as opposed to economic development and governmental structure. This literature has developed in two strands: qualitative and comparative analyses of the cultural and social factors related to violations of personal integrity and quantitative studies striving to model these violations in a crossnational or time-series framework (Hafner-Burton and Ron 2009). Unlike the literatures on either economic development or democratic consolidation and human rights practices, the quantitative study of domestic repression has no a priori expectation for its effect on public support for torture and other forms of state violence.

The cases of Australia and France are illustrative of qualitative research on torture and its effect on public opinion. The sensation of the water torture of a woman by Australian soldiers during the Vietnam War caused a considerable stir in parliament and in the media, but the episode quickly faded to the point that it is virtually forgotten today (Ekins 1996). Conversely, Louisette Ighilahriz sparked an uproar in French society when she came forward in 2000 in an attempt to find the doctor who rescued her after being raped and tortured by French paratroopers during the Algerian War for Independence (1954-1962). ${ }^{5}$ In both cases, a public outcry followed disclosures of torture by a government not known for its use of torture. Despite a similarity of context, Australian torture during the Vietnam War is largely forgotten, while images of French torture in Algeria vividly persist through time.

Research on torture, and human rights violations in general, is limited by the relative scarcity of data. "[R]eliable and comprehensive data in the human rights area, especially in forms that lend themselves to either longitudinal or cross-national studies, are often not available due to lack of collection or to governmentally-imposed barriers. Where data are available, they will often be extremely difficult and expensive to obtain, and are likely to be fragmentary, controversial or of dubious reliability" (Goldstein 1992, 41). In the absence of reliable data, research into state violence is often pursued by examining particular cases of its occurrence to distill general patterns, though recent development of ratings of domestic repression allow for more sophisticated analyses.

In the absence of reliable data on instances of torture and other violations of personal integrity, quantitative investigations of the subject use impressionistic

\footnotetext{
${ }^{5}$ See Shatz (2002) for a summary of this episode and its context. For a general history of torture in the French-Algerian War, see Lazreg (2008) or Vidal-Naquet (1963). The memoirs of the military commander (Massu 1971) and the chief of intelligence (Aussaresses 2002) also discuss the role of torture in the conflict. Horne (1977) provides a general history of the war.
} 
characterizations of governmental respect for human rights as a proxy for actual violations of human rights. Two such measures, the Political Terror Scale (PTS; Gibney and Dalton 1996) and the Cingranelli-Richards Index (CIRI; Cingranelli and Richards 1999b), score countries' human rights practices according to the content of annual State Department (Innes 1992) and Amnesty International (Ron et al. 2005) country reports. Poe et al. (2001) find that, in the vast majority of cases, State Department and Amnesty International scores are equal, suggesting these measures are an unbiased assessment of human rights practices around the world. Cross-national surveys have shown that the people accurately perceive the government's use of domestic repression. (Carlson and Listhaug 2007; Anderson et al. 2002, 2005).

\section{Hypotheses}

No study has yet examined international public opinion on the question of torture directly. More importantly, from a theory-building perspective, an effort to explain what factors may influence relative rates of approval of torture is absent from the literature. This paper attempts to fill this gap by testing three hypotheses developed to explain observed levels of public support for torture in 31 countries.

Increasing economic growth is associated with greater respect for human rights. Rising personal income levels create a more educated and informed public, who, over time, express a cosmopolitan worldview that prioritizes self-expressive values over materialist values. Macroeconomic growth and integration with the global economic system is also associated with greater respect for human rights. Thus, we expect an inverse relationship between per capita income and torture approval:

Hypothesis 1 States with high levels of per capita income disapprove of torture.

Democracy can mean many things to different people. However, at its core, the democratic state is one that espouses values of equality, pluralism, rule of law, and, most importantly, limits on governmental power. While the social science literature on the relationship between democracy and human rights is mixed, torture is incongruent with the foundational values of the democratic state.

\section{Hypothesis 2 States that limit executive power disapprove of torture.}

The development of quantitative measures of violations of personal integrity allow for analyses to compare the repressive practices of governments to public approval of torture. Survey data suggest that the public has a keen sense of the government's protection of personal integrity rights. The cases of France and Australia provide examples of the public's strong reaction to the 
use of torture when it is an extraordinary exception. Thus, we expect a positive relationship between the absence of domestic repression and torture approval.

Hypothesis 3 States where torture is not a common practice are opposed to torture.

After testing each individual hypothesis, a multiple regression is used to test joint effects among the independent variables. We find that higher per capita income, stable democratic norms, and a lack of domestic repression are related with higher levels of public opposition to torture.

\section{Data}

Two cross-national surveys conducted in 2006 and 2008 provide the dependent variable for this study. ${ }^{6}$ The 2006 survey was sponsored by the BBC and conducted by the polling firm GlobeScan with PIPA. This poll includes 27,407 respondents in 25 countries. The 2008 survey includes 19,556 respondents in 22 countries, 16 of which were included in the 2006 poll. $^{7}$ Table 1 details the coverage of these two surveys.

These surveys followed a common format. Respondents were asked

$[\mathrm{m}]$ ost countries have agreed to rules that prohibit torturing prisoners. Which position is closer to yours?

- Terrorists pose such an extreme threat that governments should now be allowed to use some degree of torture if it may gain information that saves innocent lives.

- Clear rules against torture should be maintained because any use of torture is immoral and will weaken international human rights standards against torture.

A follow-up question was asked to those who selected the first option, asking if they still agreed that torture should be permitted in cases that have

\footnotetext{
${ }^{6}$ The 2006 survey was conducted between May 26 and July 6 . The 2008 survey was conducted between January 10 and May 6, except for Poland, which was polled between November 29 and December 4, 2007. The author has no connection to PIPA, nor did the author have any role in the surveys used in this paper.

${ }^{7}$ In most cases, a national sample survey was used. However, urban populations were surveyed in both the 2006 and 2008 polls in eight countries. In three of these cases (Indonesia, Turkey, and South Korea), different sample populations were used in the 2006 and 2008 polls. To ensure comparability across and within cases, the 2006 surveys of these three countries are not included in the bivariate tests of each hypothesis or the multiple regression. Only the 2008 survey data (using a national sample) are included in these analyses.
} 
Table 1 List of countries and survey details

\begin{tabular}{|c|c|c|c|}
\hline Country & Year(s) & Sample size & Survey population \\
\hline Argentina & 2008 & 675 & Urban \\
\hline Australia & 2006 & 1,007 & National \\
\hline Azerbaijan & 2008 & 602 & National \\
\hline Brazil & 2006 & 800 & Urban \\
\hline Canada & 2006 & 1,007 & National \\
\hline Chile & 2006 & 1,000 & National \\
\hline China & 2006 and 2008 & $1,800 / 1,000$ & Urban/urban \\
\hline Egypt & 2006 and 2008 & $1,000 / 600$ & Urban/urban \\
\hline France & 2006 and 2008 & $1,000 / 600$ & National/national \\
\hline Germany & 2006 & 1,002 & National \\
\hline Hong Kong & 2008 & 1,018 & National \\
\hline India & 2006 and 2008 & $1,639 / 1,023$ & National/national \\
\hline Indonesia & 2006 and 2008 & $1,000 / 811$ & Major cities/national \\
\hline Iran & 2008 & 710 & National \\
\hline Iraq & 2006 & 2,000 & National \\
\hline Israel & 2006 & 1,008 & National \\
\hline Italy & 2006 & 1,004 & National \\
\hline Kenya & 2006 and 2008 & $1,002 / 1,000$ & National/national \\
\hline Mexico & 2006 and 2008 & $1,000 / 850$ & National/national \\
\hline Nigeria & 2006 and 2008 & $1,000 / 1,000$ & National/national \\
\hline Palestine & 2008 & 626 & National \\
\hline Philippines & 2006 & 1,000 & Urban \\
\hline Poland & 2006 and 2008 & $1,041 / 626$ & National/national \\
\hline Russia & 2006 and 2008 & $1,045 / 792$ & National/national \\
\hline South Korea & 2006 and 2008 & $1,000 / 600$ & Major cities/national \\
\hline Spain & 2006 and 2008 & $1,028 / 600$ & National/national \\
\hline Thailand & 2008 & 2,699 & National \\
\hline Turkey & 2006 and 2008 & $1,000 / 719$ & Urban/national \\
\hline Ukraine & 2006 and 2008 & $1,018 / 1,021$ & National/national \\
\hline UK & 2006 and 2008 & $1,004 / 800$ & National/national \\
\hline USA & 2006 and 2008 & $1,002 / 940$ & National/national \\
\hline
\end{tabular}

nothing to do with terrorism. This paper only focuses on the initial question since it provides the broadest sample of respondents for a comparative analysis.

This question format makes a few assumptions of the application of torture. First, torture would only be applied to terrorists, an exceptional class of criminal that is apart from good and proper citizens (Parry 2010; Einolf 2007). This also suggests that traditional law enforcement methods are unable to cope with the unique character of terrorist acts. Second, respondents are asked to evaluate a set of techniques instead of specific methods. If the American public is any guide, approval of specific techniques tend to vary significantly (Gronke et al. 2010; Richards and Anderson 2007). Third, the pro-torture view hinges on the protection of innocent lives, a utilitarian argument presented elsewhere (Bagaric and Clarke 2007; Yoo 2006).

The anti-torture response is similarly loaded with suppositions. First, it is possible that prefacing the question by establishing torture is already prohibited in many places may inflate the proportion of respondents answering in the negative. Second, this response includes a devotion to clear rules (and 


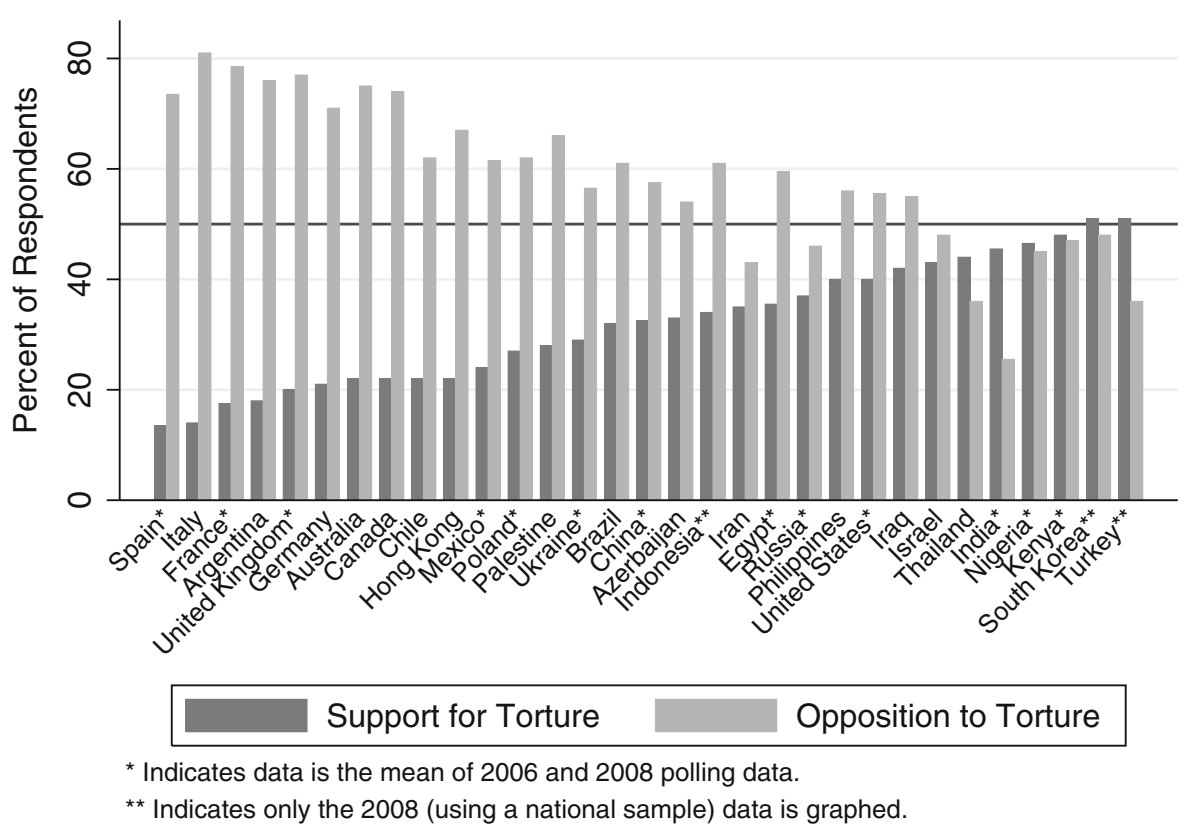

Fig. 1 Approval of torture in 31 countries

presumably punishments for violating those rules). The breakdown of order is associated with outbursts of violence (Zimbardo 2007). Third, it relies on a collective, normative understanding of torture as something the international community does not support. We would expect countries to enforce norms against torture, but if countries defect from this understanding and commit torture, the value of an international regime banning the use of torture is reduced. ${ }^{8}$

Figure 1 graphs levels of approval of torture in the 31 countries surveyed in 2006 and 2008 in order of increasing acceptability. ${ }^{9}$ A number of patterns present themselves. There appears to be considerable public opposition to the use of torture. In 22 cases, majorities are opposed to torture. Pluralities are

\footnotetext{
${ }^{8}$ Nonetheless, this survey question and the small number of others like it used to gauge approval of torture outside the USA include the application of torture to terrorists, the need for information, and the aim of saving innocent lives. Unfortunately, there are no such questions from before the attacks on the USA on September 11, 2001, so it is difficult to determine the extent of the influence on the survey question from the context of the war on terror and its use of torture. No cross-national survey we are aware of ask respondents to categorize a set of techniques as torture. Thus, it is impossible to isolate, say, water torture from the general set of coercive tactics that may be used in detention, but there is no apparent survey instrument that can answer such a specific inquiry into the dynamics of torture approval.

${ }^{9}$ While neither Hong Kong nor the Palestinian Territories are countries in the Weberian sense of a monopoly on the legitimate use of force, the term is used when referring to the set of surveyed jurisdictions.
} 
opposed to torture in Iran, Israel, and Russia. Pro-torture pluralities are found in four cases: Thailand, India, Nigeria, and Kenya. South Korea and Turkey report slim majorities in favor of torture- $51 \%$ in both cases.

Western European countries, including Canada and Australia, are the most opposed to the use of torture. Latin American countries are, as a cohort, slightly more accepting of torture than the western European countries, but by no means in favor of the practice. Eastern European and Middle Eastern countries appear roughly in the third tier of opposition. Asian and Southeast Asian countries are in the fourth tier, comprised of publics divided on the question of torture. African countries, exhibiting pluralities in favor of torture, are found at the right hand of Fig. 1. According to these broad regional classifications, the USA and Israel appear to be separated from their peer groups. ${ }^{10}$ We will see below that American opinions on torture are exceptional when considering its standing along the three tested dimensions in this analysis.

The split in the Israeli public on the question of torture is emblematic of the general debate between security imperatives and protection of personal integrity. The landmark 1999 Supreme Court decision that banned the use of torture by the General Security Service expresses the concern for security in the face of a domestic threat ${ }^{11}$

Ever since it was established, the State of Israel has been engaged in an unceasing struggle for its security-indeed, its very existence. Terrorist organizations have set Israel's annihilation as their goal. Terrorist acts and the general disruption of order are their means of choice. In employing such methods, these groups do not distinguish between civilian and military targets. They carry out terrorist attacks in which scores are murdered in public areas-in areas of public transportation, city squares and centers, theaters and coffee shops. They do not distinguish between men, women and children. They act out of cruelty and without mercy (4).

Under such conditions, we might expect public approval of torture to be high. Consider that timely and accurate information has the potential to save innocent lives, and security agencies may be more likely to resort to torture to get that information. That being said, the Court in this case ultimately rejects the arguments in favor of allowing torture techniques to be used by the security services

This is the destiny of democracy-it does not see all means as acceptable, and the ways of its enemies are not always open before it. A democracy must sometimes fight with one hand tied behind its back... We are, however, part of Israeli society... We live the life of this country. We are aware of the harsh reality of terrorism in which we are, at times, immersed. The possibility that this decision will hamper the ability to

\footnotetext{
${ }^{10}$ Regional dummy variables are included in multiple regression results below.

${ }^{11}$ See Public Committee Against Torture v. Israel (HCJ 5100/94).
} 
properly deal with terrorists and terrorism disturbs us. We are, however, judges. We must decide according to the law (36-37).

The Israeli public is divided on the question of torture. However, the state of Israel is also a member to the CAT (ratified in 1991), which imposes a series of obligations upon the state regarding protection of personal integrity rights. After this Court ruling, a bill was introduced to officially legalize the actions the Court had proscribed. Yet, as Simmons notes, legislating torture in a democratic forum is not politically feasible; the bill did not pass (Simmons 2009, 303).

In 13 other cases, we can observe the change in sentiment across two time points. ${ }^{12}$ Table 2 displays the observed change in support for torture in these cases. ${ }^{13}$ The observed change in sentiment appears to tilt toward opposition to torture. Four countries moved toward acceptance of torture, seven became more opposed, and Poland did not move from its opposition. Majorities that were opposed to torture in Kenya and Nigeria in 2006 were replaced by majorities in favor of torture in 2008. Egypt and the USA moved closer to outright support of torture. India, the only country with a plurality in favor of torture in 2006, increased its acceptance of torture in 2008. Conversely, China, Mexico, and Spain hardened their opposition to torture. The magnitude of the shifts in public opinion is almost exactly split: The sum of shifts in opposition is 114 and the sum of shifts in support is 122. International news coverage of torture in Iraq and elsewhere appears to have shifted sentiment within these 13 states - with the exception of Poland - though the aggregate shift is almost neutral.

This paper tests three hypotheses to explain relative levels of approval of torture in these surveyed countries. To test these hypotheses, data from three sources were collected. First, per capita income data were collected for each country in 2006 and 2008 from the International Monetary Fund World Economic Outlook Database (April 2009). Per capita income is measured according to purchasing power parity and reported in current American

\footnotetext{
${ }^{12}$ The reliability of the survey instrument can be tested by comparing these data to other surveys on torture approval. However, the universe of public opinion data on cross-national torture approval is small. To wit, there are no publicly available cross-national surveys of torture approval after 2008 , making it difficult to assess the change in approval in these 13 countries. That being said, two surveys, in 2005 and 2006, measure torture approval in a smaller number of countries and with a slightly different question format. A 2005 survey by the Associated Press and Ipsos Public-Affairs polled France, Mexico, Spain, the UK, and the USA. A 2006 survey by the Chicago Council on Global Affairs measured torture approval in China, India, and the USA. The AP/Ipsos data accord with the 2006 PIPA data for Mexico (a difference of 1 percentage point between the two surveys), Spain ( 0 percentage point), the UK ( 9 percentage points), and the USA ( 1 percentage point); opposition to torture is lower in the AP/Ipsos data for France than in the PIPA data (23 percentage points). The 2006 Chicago Council data accord with the PIPA India data (1 percentage point difference), but diverge from the USA (15 percentage points) and China (39 percentage points) data.

${ }^{13}$ The difference between opposition and support is reported in the table. According to this formulation, smaller and negative numbers indicate a public increasingly indecisive and protorture, respectively. Larger, positive numbers indicate a public increasingly opposed to torture.
} 
Table 2 Change in difference between torture opposition and support

\begin{tabular}{lccc}
\hline Country & 2006 difference & 2008 difference & Change \\
\hline China & 12 & 38 & +26 \\
Egypt & 40 & 8 & -32 \\
France & 56 & 66 & +10 \\
India & -9 & -31 & -22 \\
Kenya & 15 & -17 & -32 \\
Mexico & 26 & 49 & +23 \\
Nigeria & 10 & -13 & -23 \\
Poland & 35 & 35 & 0 \\
Russia & 6 & 13 & +7 \\
Spain & 49 & 71 & +22 \\
Ukraine & 25 & 33 & +8 \\
UK & 48 & 66 & +18 \\
USA & 22 & 9 & -13 \\
\hline
\end{tabular}

dollars. Observed income levels range from about $\$ 1,500$ (Kenya) to over $\$ 45,000$ (USA). ${ }^{14}$

Second, a quantitative measure of democratization in the surveyed countries in 2006 and 2008 is included in model estimates. One factor that emerged in the literature on democracy and human rights is the importance of constraining the power of the executive. Torture and other violations of personal integrity are less likely to occur when there are many actors monitoring the actions of the executive. To test this hypothesis, Polity IV data on executive constraints is used in analyses below. The xconst variable is a component part of the Polity IV measure of institutionalized democracy. ${ }^{15}$ The variable ranges from 1 (unlimited executive authority) to 7 (executive parity or subordination). ${ }^{16}$ The surveyed countries include a number of established and new democratic regimes as well as non-democratic regimes.

Third, a measure of domestic repression is included in model estimates. Data from the PTS is used to quantify the level of state repression in each of these countries. ${ }^{17}$ PTS scores range from 1 to 5 , where lower scores indicate a greater degree of security from personal integrity violations (Gibney and Dalton 1996). This scale is reversed for the purposes of this paper; a score of 5 is indicative of countries "under a secure rule of law, people are not imprisoned for their views, and torture is rare or exceptional. Political murders are extremely rare" and decreasing PTS scores indicate an increasing level of

\footnotetext{
${ }^{14}$ The average per capita income is just over $\$ 17,000$; the standard deviation is $\$ 13,600$. No income data are available for the Palestinian Territories.

${ }^{15}$ See http://www.systemicpeace.org/polity/polity4.htm for country data and the rating methodology.

${ }^{16}$ The Polity data on executive constraints is highly correlated with the Polity democracy measure (0.95) or the Freedom House measure of democracy (0.87), but the correlation between executive constraints and either of the other explanatory variables is lower than both Freedom House and Polity top-level measures of institutionalized democracy.

${ }^{17}$ Additional information on this scale and 1976-2008 data can be found here: http://www. politicalterrorscale.org.
} 
domestic repression. ${ }^{18}$ The average of all available data for each country is used in this paper. ${ }^{19}$

The surveyed countries exhibit different national experiences with torture. According to PTS data, Australia and Canada have the lowest frequency of domestic repression (on a scale to 5, these countries score 4.92 and 4.98, respectively). ${ }^{20}$ Conversely, torture is rife in Iraq, as evidenced in part by the discovery of torture chambers by American soldiers, most notably in 2007 in the Sadr City district of Baghdad.

Before turning to the findings of this study, the results of a series of diagnostic analyses are presented. First, one might question if the dataset is of sufficient size to adequately study the relationship between torture approval and national-level explanatory variables. However, power analysis indicates the dataset has a sufficient number of observations. ${ }^{21}$ Second, heteroskedasticity is not present in the data. ${ }^{22}$ Third, severe multicollinearity is present in the data. ${ }^{23}$ However, it is not clear how to best correct for multicollinearity. The optimal solution, adding more observations, is not available in this case. Multicollinearity inflates standard errors but does not bias results. Thus, we accept a certain degree of collinearity that is inevitable between the modeled variables.

\section{Findings}

We now turn to testing the hypotheses identified above. Figure 2 graphs per capita income against the observed difference in public opinion on torture in 30 cases. The trend shows that higher levels of per capita income are related with higher levels of opposition to torture, but opposition to torture decreases

\footnotetext{
${ }^{18}$ There is an alternate measure of domestic repression. The Cingranelli-Richards Index assess (1) the frequency of torture and (2) the frequency of general violations of personal integrity (see Cingranelli and Richards 1999b). However, The PTS and Cingranelli-Richards measures substantially tap the same dimension. The correlation between the PTS scores and the CingranelliRichards measures of torture frequency for the surveyed countries is 0.92 . The correlation between the PTS scores and the general index generated by Cingranelli and Richards is 0.96 . See Wood and Gibney (2010) for a comparison of PTS and CIRI.

${ }^{19}$ Eight cases have less than full data on this variable. There is no PTS measure of political terror in Hong Kong. Scores for Germany are from 1989 to 2006. Azerbaijan, Russia, and Ukraine are scored based on reports from 1992 to 2008. Israel and the Palestinian Territories are disaggregated and scored separately, based on reports from 1994 to 2008.

${ }^{20}$ However, Parry (2010) observes that recent cases of torture of terrorists have involved at least the tacit consent of state officials from Canada, Italy, and Sweden.

${ }^{21}$ The power rate is the probability of rejecting a false null hypothesis. Given 41 observations, the power rate for this dataset is 0.9784 . This statistic is calculated by means of the powerreg command in Stata.

${ }^{22}$ The Breusch-Pagan $\chi^{2}$ is $0.40(p<0.53)$.

${ }^{23}$ The variance inflation factor for the model as a whole is 9.17. When the VIF is disaggregated, only the income variables exhibit severe multicollinearity, which is not surprising given one is a transformation of the other variable.
} 


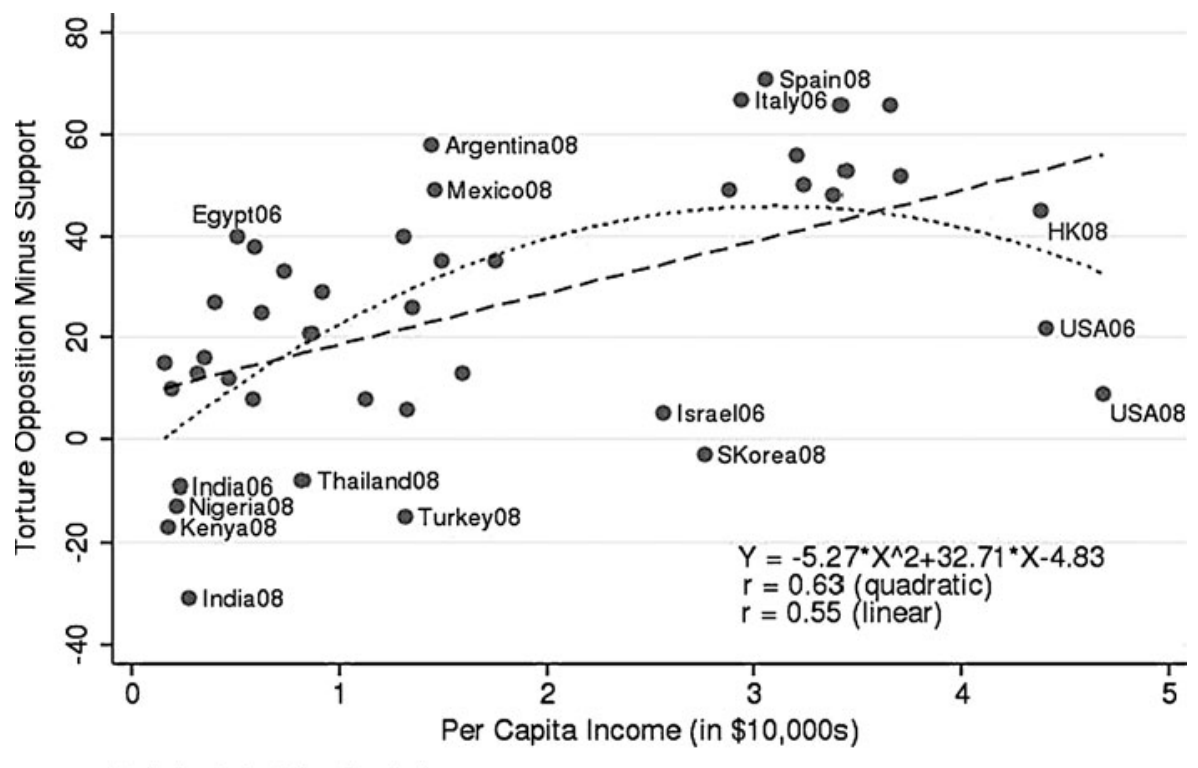

Excludes Palestinian Territories.

Fig. 2 Torture opposition and pre capita income

as per capita income rises above about $\$ 31,000$. The relationship between torture approval and per capita income is better described by including an income-squared term. ${ }^{24}$ The available evidence supports the first hypothesis that increasing per capita income will lead to greater support for the rejection of torture. However, the US and South Korea are two notable outliers in this bivariate analysis.

We may be surprised to see that the USA, the country with the highest level of per capita income among the surveyed countries, does not have the highest level of opposition to torture. However, as Inglehart and Welzel have observed, "[T]he United States is not a prototype of cultural modernization for other countries to follow, as some postwar modernization writers assumed. In fact, the United States is a deviant case, having a much more traditional value system than any other postindustrial society except Ireland" (65). Therefore, we should expect the USA to fall below predicted levels-based on per capita income - of a number of indicators of sentiments, including the role of religion in daily life, roles within the family, and other items included in the World Values Survey. It appears that approval of torture is no different in this regard.

South Korea is another case where per capita income does not predict the public's opinion on torture. One possible explanation for the South Korean

\footnotetext{
${ }^{24}$ The goodness of fit measure increases from 0.55 in the linear model to 0.63 in the quadratic model.
} 
public's view on torture may be Inglehart's socialization hypothesis: There is a lag between the onset of economic development and the corresponding value change among the population. "Ten or fifteen years after an era of prosperity began, the age cohorts that had spent their formative years in prosperity would begin to enter the electorate. Another decade or two might pass before they begin to play elite roles" (Inglehart and Welzel, 99). If this is true, then the sentiments of students and intellectuals may be most indicative of where public sentiment in South Korea is headed in the near future. One observer noted that the students in South Korea in the early 1990s exemplified "many undemocratic elements, such as factionalism and alienation, and have in part hindered the development of democracy and democratic culture by their radicalism, inflexibility and overzealous protest... The essential problem... is a lack of moderation, tolerance, and a willingness to compromise" (Diamond 1993, 20). The sentiments exhibited by students in the 1990s do not suggest self-expressive values like the rejection of torture have been adopted by the public at large by the time of these surveys.

Now let us turn to the relationship between democratic consolidation and approval of torture. Figure 3 displays the relationship between opposition to torture and the Polity data on executive constraints. The available data weakly support the hypothesis that constrained executives result in greater opposition to torture. The best fit line has positive slope, but a low correlation with the data. Iran and the USA in 2008 exhibit about the same degree of opposition

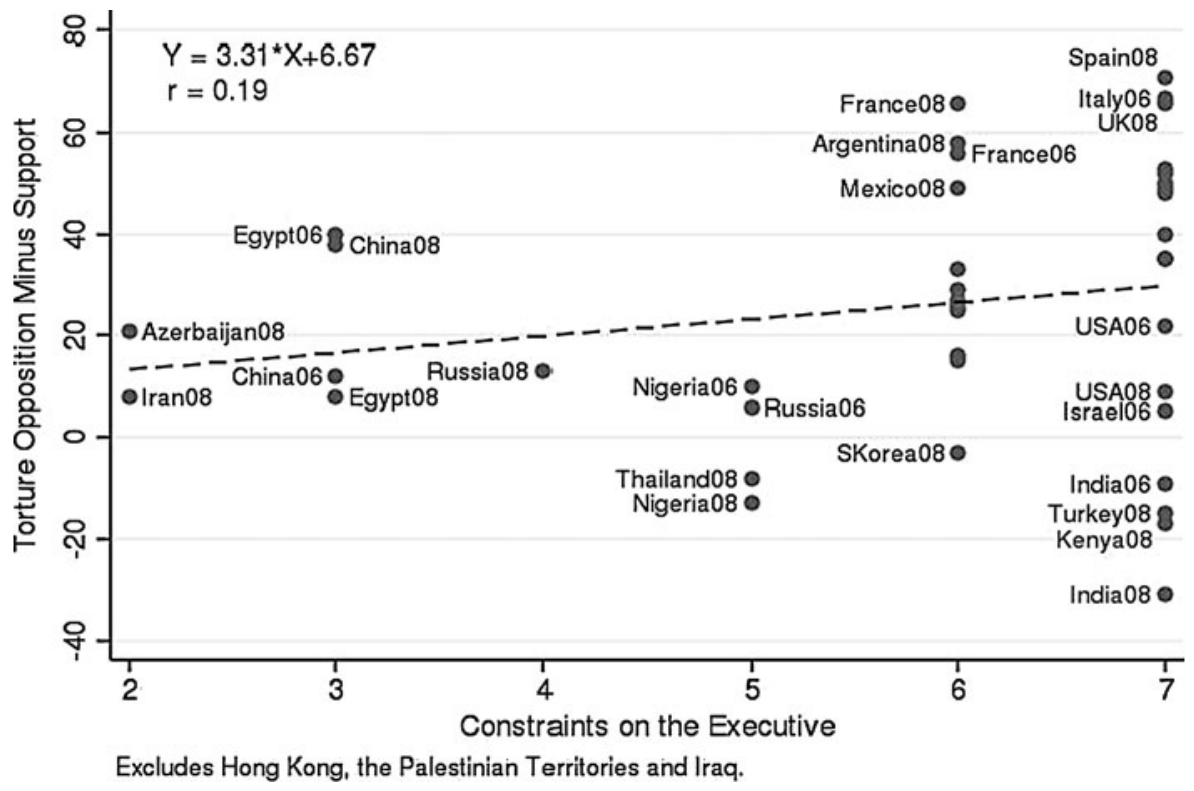

Fig. 3 Torture opposition and executive constraints 


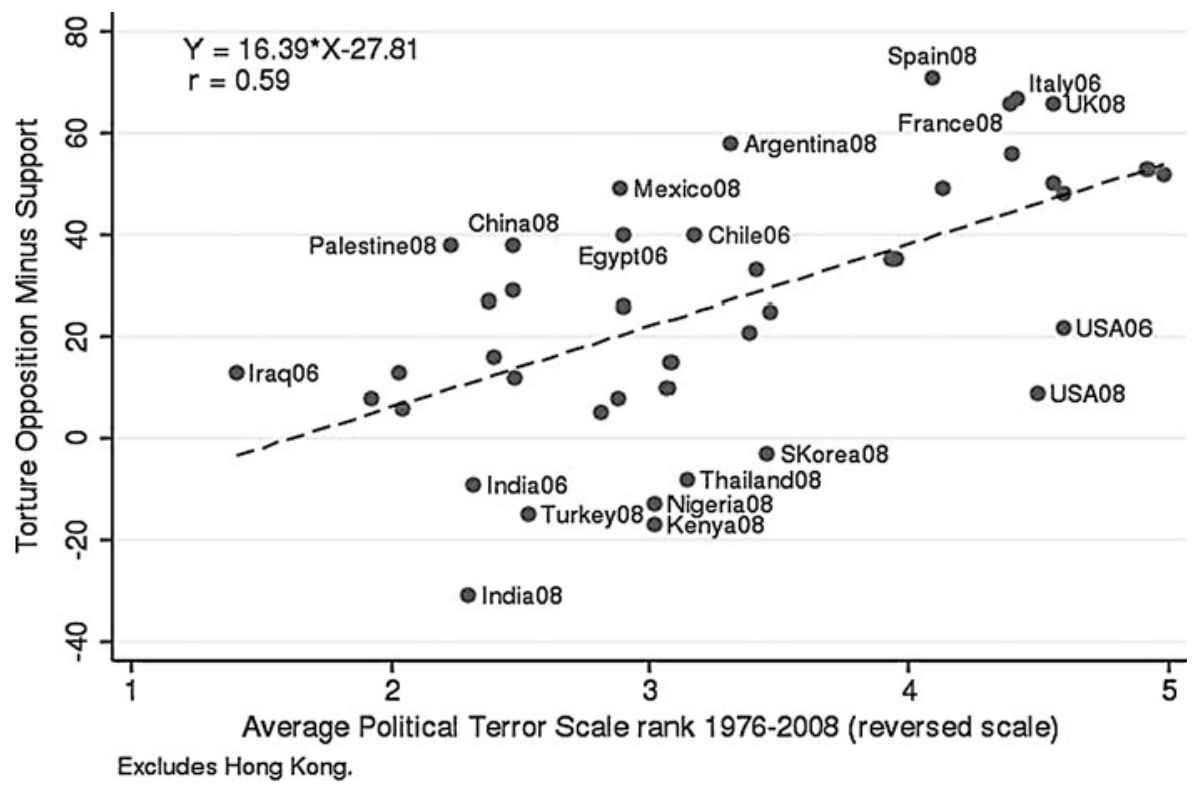

Fig. 4 Torture opposition and domestic repression

to torture, but the American president is far more constrained than his Iranian counterpart. Further, all the countries that have net support for torture also have at least substantial limitations on executive authority. ${ }^{25}$

Next, we turn to the relationship between domestic repression and support for torture. Figure 4 shows a positive, linear correlation between the absence of domestic repression and the rejection of torture among the surveyed publics. In general, we see evidence for dynamic representation insofar as the countries that are most opposed to torture are also the same countries where domestic repression is least likely to occur. The USA again appears to be an outlier, as it is the only country with a PTS score above 4 that is close to a split in approval of torture. A group of six countries broadly supportive of torture are also a set of outliers in the figure. These six countries are in the middle of the PTSbetween 2.3 and 3.45 on this reversed scale-demonstrating that torture is most approved of in countries where "There is extensive political imprisonment, or a recent history of such imprisonment. Execution or other political murders and brutality may be common. Unlimited detention, with or without a trial, for political views is accepted."

Finally, we estimate a multiple regression using ordinary least squares. As suggested by the above bivariate correlations, we expect the linear per capita income term to be positive, but the income-squared term to be negative.

${ }^{25}$ This is the meaning behind a Polity score of five for the xconst variable. 
Table 3 Multiple regression model of torture approval

Standard errors in parentheses. Africa and the Middle East are the excluded category in (2)

$* p<0.05 ; * * p<0.01$

\begin{tabular}{lll}
\hline Torture opposition & $(1)$ & $(2)$ \\
\hline Per capita income & $29.05^{* *}(8.58)$ & \\
Per capita income $^{2}$ & $-6.84^{* *}(1.97)$ & \\
Executive constraint & $-3.11(2.19)$ & \\
Political terror scale & $21.86^{* *}(5.70)$ & \\
Europe & & $34.38^{* *}(8.98)$ \\
Americas & & $24.93^{*}(10.13)$ \\
Asia & $-46.85^{*}(31.02)$ & $3.15(8.98)$ \\
Constant & 0.57 & $10.7(6.75)$ \\
$R^{2}$ & 41 & 0.35 \\
$N$ & & 44 \\
\hline
\end{tabular}

Executive constraints and domestic repression should be positively related to the dependent variable. The results of the regression are presented in Table 3.

The signs of the income and domestic repression variables are in the expected direction. Per capita income is significant, though the curvilinear relationship identified in the bivariate analysis is also present in the multiple regression results. Decreasing domestic repression is found to be associated with greater opposition to torture. The regional dummy variables conform with the discussion of torture approval in Fig. 1. The sign on the executive constraints variable is negative, but also not statistically significant.

One must be cautious when attributing causation on the basis of these data. On the one hand, we have strong theoretical reasons for thinking an increase in per capita income or democratic consolidation would lead to lower levels of support for torture. Similarly, one could claim that domestic repression would lead to changes in the level of public support for torture. But such a claim would depend on knowing the level of support for torture before a period of economic development, before a democratic regime was established, or before secret police started using extreme methods of interrogation. And, unfortunately, such data do not exist. The best we can do in this circumstance is observe that these data support the general thrust of two of the three hypotheses. More affluent and less repressed countries tend to oppose the use of torture in greater proportions than other countries, other things being equal.

\section{Conclusions}

The broad purpose of this paper is to relate two previously disconnected subjects: public opinion and torture. As other scholars have noted, the role of intrastate violence is not well examined. This study demonstrates that such forms of violence can be compared to other sets of data and meaningful inferences can be made from these comparisons.

This is the first effort to explain observed variations in support of torture on a cross-national, comparative basis. Using survey data from 31 countries, we find support for the claims that high per capita income and low domestic repression are associated with greater opposition to torture. Democratic 
consolidation has no significant effect on public approval of torture. Opposition to torture, therefore, is a function of economic development-and the subsequent postmaterialist value change paradigm - and the national experience with domestic repression.

Three contributions of this study were identified at the outset. First, this paper broadens public opinion on torture beyond American surveys. Consistent with American polling on the question of torture, we find support for torture is rare. Of the 31 countries in these surveys, only two have a slim majority in favor of torture. Second, previous cross-national surveys have been concerned with mass perceptions of human rights. This study focuses on torture as a specific form of violence. The findings here support the previous studies of public opinion in regards to perceptions of human rights practices. The expectations established by studies examining human rights in general are support by this study of a specific violation of these rights. Lastly, in line with the dynamic representation model, we find that, even among countries dedicated to the elimination of torture as defined by the CAT, countries most opposed to torture are least likely to use it and other forms of domestic repression.

However, the results also highlight potential areas for further research. Consider the relationship between per capita income and torture approval identified in Fig. 2. The cases of Hong Kong and the USA (the only cases with income levels above $\$ 40,000$ ) pull the best fit line down at high income levels, creating a curvilinear relationship. It is unclear if this relationship would remain if additional high-income countries were included in the analysis. One could reasonably expect the Scandinavian countries to reflect the opinions of western Europe, shifting the best fit line toward a linear relationship. On the other hand, oil-rich countries, which do not have records of protecting personal integrity rights, may pull the curvilinear slope down further. Further exploration of public approval of torture among high-income countries is warranted by these findings.

This study also suggests that the function of violence, particularly in transitional regimes, is worthy of further study. Previous research (in particular Fein 1995) suggests that regimes introducing democracy may be victim to greater domestic repression. The finding of this study complicate the story of democratic transitions by suggesting that the transitional regimes are also the most likely to approve of these same repressive state actions. Perhaps governments that torture do so because social dynamics incentivize repressive policies toward an out-group (e.g., torture against the Kurds in Turkey would have few, if any, electoral impacts for the government given the historical roots of Kurdish resistance to the Turkish regime).

Torture is, to use Vidal-Naquet's phrase, the cancer of democracy. Recent events in the USA have led to a reinvigorated interest in torture as a means to prevent future terrorist attacks. However useful torture may be in that regard-and the available evidence suggests the efficacy of torture is exaggerated - the use of torture is clearly an unpopular course of action fraught with peril for the government agents who may resort to its use. 
Open Access This article is distributed under the terms of the Creative Commons Attribution Noncommercial License which permits any noncommercial use, distribution, and reproduction in any medium, provided the original author(s) and source are credited.

\section{References}

Anderson, Christopher, Aida Paskeviciute, Maria Sandovici and Yuliya Tverdova. 2005. "In the Eye of the Beholder? The Foundations of Subjective Human Rights Conditions in EastCentral Europe.” Comparative Political Studies. Vol. 38, No. 7: 771-798.

Anderson, Christopher, Patrick Regan and Robert Ostergard. 2002. "Political Repression and Public Perceptions of Human Rights." Political Research Quarterly. Vol. 55, No. 2: 439-456.

Aussaresses, Paul. 2002. The Battle of the Casbah: Terrorism and Counterterrorism in Algeria 19551957. Robert Miller (trans.). New York: Enigma Books.

Bagaric, Mirko and Julie Clarke. 2007. Torture: When the Unthinkable Is Morally Permissible. Albany: State University of New York Press.

Bueno de Mesquita, Bruce, George Downs, Alastair Smith and Feryal Marie Cherif. 2005. "Thinking Inside the Box: A Closer Look at Democracy and Human Rights." International Studies Quarterly. Vol. 49: 439-457.

Carlson, Matthew and Ola Listhaug. 2007. "Citizens' Perceptions of Human Rights Practices: An Analysis of 55 Countries.” Journal of Peace Research. Vol. 44, No. 4: 465-483.

Cingranelli, David and Mikhail Filippov. 2010. "Electoral Rules and Incentives to Protect Human Rights.” Journal of Politics. Vol. 72, No. 1: 243-257.

Cingranelli, David and David Richards. 1999a. "Respect for Human Rights After the End of the Cold War." Journal of Peace Research. Vol. 36, No. 5: 511-534.

Cingranelli, David and David Richards. 1999b. "Measuring the Level, Pattern and Sequence of Government Respect for Physical Integrity Rights.” International Studies Quarterly. Vol. 43, No. 2: 407-417.

Conrad, Courtenay and Will Moore. 2010. "What Stops the Torture?" American Journal of Political Science. Vol. 54, No. 2: 459-476.

Conroy, John. 2000. Unspeakable Acts, Ordinary People: The Dynamics of Torture. New York: Knopf.

Dahl, Robert. 1971. Polyarchy: Participation and Opposition. New Haven: Yale University Press.

Davenport, Christian. 2007a. "State Repression and Political Order." Annual Review of Political Science. Vol. 10: 1-23.

Davenport, Christian. 2007b. State Repression and the Domestic Democratic Peace. New York: Cambridge University Press.

Davenport, Christian. 2004. "The Promise of Democratic Pacification: An Empirical Assessment." International Studies Quarterly. Vol. 48, No. 3: 539-560.

Davenport, Christian. 1999. "Human Rights and the Democratic Proposition." Journal of Conflict Resolution. Vol. 43, No.1: 92-116.

Davenport, Christian and David Armstrong. 2004. "Democracy and the Violation of Human Rights: A Statistical Analysis from 1976 to 1996." American Journal of Political Science. Vol. 48, No. 3: 538-554.

Diamond, Larry. 1993. "Introduction: Political Culture and Democracy" in Political Culture and Democracy in Developing Countries. Larry Diamond (ed.). Boulder: Reinner. 1-33.

Einolf, Christopher. 2007. "The Fall and Rise of Torture: A Comparative and Historical Analysis." Sociological Theory. Vol. 25, No. 2: 101-121.

Ekins, Ashley. 1996. "Not One Scintilla of Evidence'?: The Media, the Military and the Government in the Vietnam Water Torture Case." Australian Journal of Politics and History. Vol. 42, No. 3: 345-364.

Fein, Helen. 1995. "More Murder in the Middle: Life-Integrity Violations and Democracy in the World, 1987." Human Rights Quarterly. Vol. 17, No. 1: 170-191. 
Gibney, Mark and Matthew Dalton. 1996. "The Political Terror Scale" in Human Rights and Developing Countries.. Stuart S. Nagel and David Louis Cingranelli, (eds.). Greenwich: JAI. 73-84.

Goldstein, Robert. 1992. "The Limitations of Using Quantitative Data in Studying Human Rights Abuses" in Human Rights and Statistics: Getting the Record Straight. Thomas Jabine and Richard Claude (eds.). Philadelphia: University of Pennsylvania Press. 35-61.

Gronke, Paul, Darius Rejali, Dustin Drenguis, James Hicks, Peter Miller and Bryan Nakayama. 2010. "U.S. Public Opinion on Torture, 2001-2009." PS: Political Science and Politics. Vol. 43, No. 3: 437-444.

Hafner-Burton, Emilie and James Ron. 2009. "Seeing Double: Human Rights Impact through Qualitative and Quantitative Eyes.” World Politics. Vol. 61, No. 2: 360-401.

Hathaway, Oona. 2002. "Do Human Rights Treaties Make a Difference?" Yale Law Journal. Vol. 111, No. 8: 1935-2042.

Heath, Anthony, Stephen Fisher and Shawna Smith. 2005. "The Globalization of Public Opinion Research." Annual Review of Political Science. Vol. 8: 297-333.

Henderson, Conway. 1991. "Conditions Affecting the Use of Political Repression." Journal of Conflict Resolution. Vol. 35, No. 1: 120-142.

Horne, Alistair. 1977. A Savage War of Peace: Algeria, 1954-1962. London: Macmillan.

Huggins, Martha, Mika Haritos-Fatouros and Philip Zimbardo. 2002. Violence Workers: Police Torturers and Murderers Reconstruct Brazilian Atrocities. Berkeley: University of California Press.

Inglehart, Ronald and Christian Welzel. 2005. Modernization, Cultural Change and Democracy: The Human Development Sequence. New York: Cambridge University Press.

Inglehart, Ronald. 1997. Modernization and Postmodernization: Cultural, Economic, and Political Change in 43 Societies. Princeton: Princeton University Press.

Inglehart, Ronald. 1990. Culture Shift in Advanced Industrial Society. Princeton: Princeton University Press.

Inkeles, Alex and David Smith. 1974. Becoming Modern: Individual Change in Six Developing Countries. Cambridge: Harvard University Press.

Innes, Judith. 1992. "Human Rights Reporting as a Policy Tool: An Examination of the State Department Country Reports" in Human Rights and Statistics: Getting the Record Straight. Thomas Jabine and Richard Claude (eds.). Philadelphia: University of Pennsylvania Press. 235-257.

Lazreg, Marnia. 2008. Torture and the Twilight of Empire: From Algiers to Baghdad. Princeton: Princeton University Press.

Massu, Jacques. 1971. La Vraie Battaille d'Alger. Paris: Plon.

Milner, Wesley, Steven Poe and David Leblang. 1999. "Security Rights, Subsistence Rights, and Liberties: A Theoretical Survey of the Empirical Landscape." Human Rights Quarterly Vol: 21. 403-443.

Mitchell, Neil and James McCormick. 1988. "Economic and Political Explanations of Human Rights Violations." World Politics. Vol. 40, No. 4: 476-498.

Parry, John. 2010. Understanding Violence: Law Violence, and Political Identity. Ann Arbor: University of Michigan Press.

Poe, Steven, Sabine Carey and Tanya Vazquez. 2001. "How are These Pictures Different? A Quantitative Comparison of the US State Department and Amnesty International Human Rights Reports, 1976-1995." Human Rights Quarterly. Vol. 23, No. 3: 650-677.

Poe, Steven, C. Tate and Linda Keith. 1999. "Repression of the Human Right to Personal Integrity Revisited: A Global Cross-National Study Covering the Years 1976-1993." International Studies Quarterly. Vol. 43, No. 2: 291-313.

Powell, Emilia and Jeffrey Staton. 2009. "Domestic Judicial Institutions and Human Rights Treaty Violation." International Studies Quarterly. Vol. 53: 149-174.

Regan, Patrick and Errol Henderson. 2002. "Democracy, Threats, and Political Repression in Developing Countries: Are Democracies Internally Less Violent?" Third World Quarterly. Vol. 23, No. 1: 119-136.

Rejali, Darius. 2007. Torture and Democracy. Princeton: Princeton University Press. 
Richards, David and Mark Anderson. 2007. "What Do US Citizens Believe About Torture and Why?" Paper Presented at the Annual Meeting of the American Political Science Association. Chicago, IL.

Richards, David, Ronald Gelleny and David Sacko. 2001. "Money with a Mean Streak? Foreign Economic Penetration and Government Respect for Human Rights in Developing Countries." International Studies Quarterly. Vol. 45: 219-239.

Ron, James, Howard Ramos and Kathleen Rodgers. 2005. "Transnational Information Politics: NGO Human Rights Reporting, 1986-2000”. International Studies Quarterly. Vol. 49, No. 3 : $557-587$.

Ron, James. 1997. "Varying Methods of State Violence." International Organization. Vol. 51, No. 2: 275-300.

Shatz, Adam. 2002. "The Torture of Algiers." The New York Review of Books. Vol. 47, No. 18: 53-57.

Simmons, Beth. 2009. Mobilizing for Human Rights: International Law in Domestic Politics. New York: Cambridge University Press.

Stimson, James, Michael Mackuen, and Robert Erikson. 1995. "Dynamic Representation." American Political Science Review. Vol. 89, No. 3: 543-565.

Verba, Sidney, Norman Nie and Jae-on Kim. 1978. Participation and Political Equality: A SevenNation Comparison. New York: Cambridge University Press.

Vidal-Naquet, Pierre. 1963. Torture: Cancer of Democracy, France and Algeria: 1954-1962. Barry Richard (trans.). Baltimore: Penguin.

Wood, Reed and Mark Gibney. 2010. "The Political Terror Scale (PTS): A Re-introduction and a Comparison to CIRI." Human Rights Quarterly. Vol. 32, No. 2: 367-400.

Yoo, John. 2006. War by Other Means: An Insider's Account of the War on Terror. New York: Atlantic Monthly.

Zanger, Sabine. 2000. "A Global Analysis of the Effect of Political Regime Changes on Life Integrity Violations, 1977-93." Journal of Peace Research. Vol. 37, No. 2: 213-233.

Zimbardo, Philip. 2007. The Lucifer Effect: Understanding how Good People Turn Evil. New York: Random House. 